\title{
Chastity belts and birthing girdles
}

\author{
Lesley Smith
}

\section{Chastity belts}

Chastity belts have been the subject of schoolroom and music hall humour for as long as most of us can remember. But did they really exist and for the purpose suggested?

My research started in 2004 with the purchase of a steel chastity belt (Figures 1 and 2). Made of solid steel with sharp spikes on the groin area, padlock plus key and with decorative toilet arrangements, my chastity belt is everything one could wish for in imagined medieval chastity.

The very appearance of this object raises eyebrows and causes much hilarity in my lectures, even in the most scholarly medical circles. I also remember having some explaining to do to security personnel at East Midlands Airport a few years ago, on my way to speak at an international sexual health conference in Edinburgh. Laughter is an appropriate response because I have reason to believe that chastity belts in this form are just a joke: a bawdy joke that seems mostly Victorian or Edwardian in origin as, indeed, is my chastity belt, which was manufactured no earlier than 1900 .

One medieval writer, Geoffrey Chaucer, must take some of the responsibility, as he refers to a "chastity belt" in The Miller's Tale. Many of the stories told on the road to Canterbury are full of bawdy humour and adultery. A chastity belt fits in wonderfully well amongst the lust and marital strife. Chaucer is an author rarely found on school curricula nowadays, but in the Victorian era his books were a key element in studying the English language, so it is hardly surprising that the chastity belt seems to have entered the music hall around about that time.

The public seem to be committed to their existence. I have been told by visitors to Tutbury Castle and at lectures how they were used by the Crusaders to lock up their wives to protect against adultery. One engineer explained how some contained spring-loaded blades to remove enquiring fingers. He could not, however, quite remember where he had seen such a device or indeed if there was any real evidence for its existence.

I have travelled abroad and looked at art collections and, as yet, haven't seen a chastity belt that can be proved to be medieval in origin. The British Museum agrees with me.

In my years looking at whorehouse accounts, early pornography and the more salacious work of pamphleteers, I have not once seen reference to chastity belts by name or description. I have not found evidence in physicians' notes of treatment of injuries caused by wearing such a device. Neither have I ever seen a note to an armourer or blacksmith giving instructions to make one.

At some levels it is not so impossible. We have 'scolds' masks' to slip over the head and hold down the tongue or pierce it as a punishment for gossips. Various other instruments of torture can be found in records - but not the chastity belt. And before any reader suggests that they

J Fam Plann Reprod Health Care 2007; 33(4): 285-286

Tutbury Castle, Tutbury, UK

Lesley Smith, Curator

Correspondence to: Lesley Smith, Tutbury Castle, Tutbury, Staffordshire DE13 9JF, UK. E-mail: info@tutburycastle.com couldn't exist earlier than the Industrial Revolution, I should like to mention at this point that steel was available in Roman times.

The next question is whether any devices related to sexual repression exist? The answer to that is a resounding 'yes'.

Those readers fortunate enough to visit the Wellcome Collection (the new and unique public venue that opened in June 2007 on London's Euston Road) may have seen some strange objects including a male anti-masturbation device. Amongst the collection can be found a strange underpantshaped object with a tight 'rhino horn' on the front to suppress erection. At last, a chastity belt, but nothing to do with the mediaevals nor with the Crusades and only linked to women by thought - and then presumably not always.
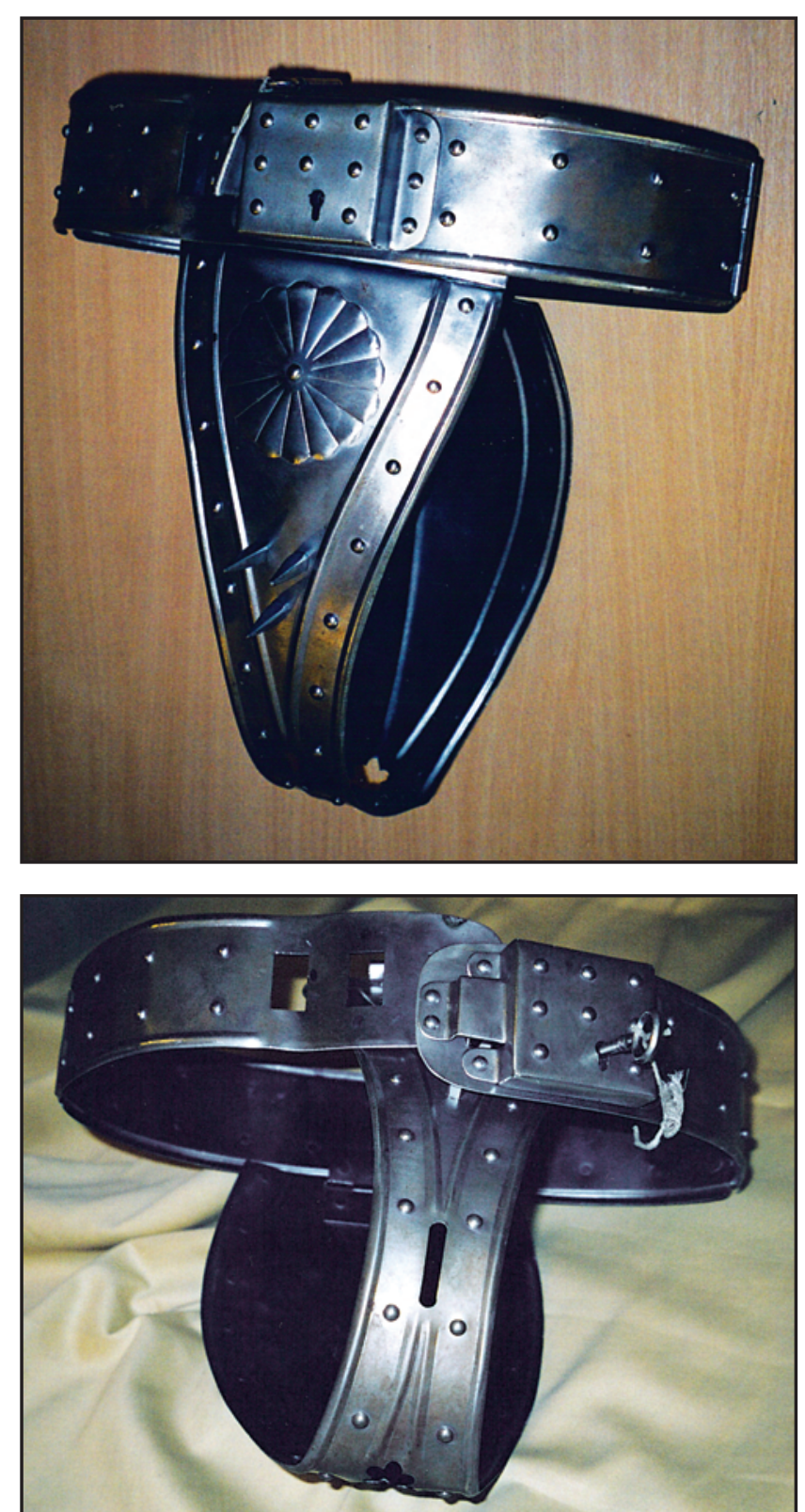

Figures 1 and 2 Solid steel chastity belt with sharp spikes on the groin area, padlock plus key and with decorative toilet arrangements owned (but not used!) by the author 
In medieval Europe any sexual activity that did not lead to conception was supposed to be forbidden. We have medieval penitentials condemning oral sex. Manual and anal sex were considered sinful and also forbidden. However, these sex acts still took place, as there is evidence of both. Thus we found the anti-masturbation device for the pious. I know a number of historians and doctors who say they have seen anti-masturbation devices for women and suggest that they were made for nuns. I have no evidence to support this claim and it is mostly conjecture.

Biographers of the 13th century St Thomas Aquinas report how he prayed for a "belt of chastity" to help him fight his lusts. Two angels were said to have appeared and bound up his loins with a belt. St Thomas Aquinas was much revered for his chastity and giving up the riches of his noble family for a life of prayer. It is possible that others tried to follow his example by wearing the aforementioned "belts of chastity".

\section{Birthing girdles}

Birthing girdles started to make a significant appearance in literature in the late medieval period. In ancient times, myths tell us of the gods girdling the earth. Erotic poems, such as those of John Donne, offer allegorical girdles replacing hands.

The idea behind such an object seems to come from an early tradition that the Virgin Mary had a girdle placed around her by angels at the start of her labour. The miraculous quality of the girdle from heaven made it a highly desirable possession. History doesn't tell us how a group of monks managed to acquire this sacred relic covered in symbols and holy writings. They could no doubt derive a lucrative return from the loan of this relic to the highest born - and the richest. King Edward I is known to have 'borrowed' the girdle for his much-loved wife during her confinements. No doubt the monks who cared for the sacred relic earned a substantial reward for their loan.

Sadly, the holy birthing girdle seems to have been lost, although I feel it might be worthwhile checking whether the Vatican Library has any reference to it. It's a pity, however, that the library is just about to be closed for 2 years for refurbishment. Though what is 2 years in half a millennium to find it again?

\section{Future articles}

The next article in this series will be on sex and quacks in the 18 th century.

\section{Author's note}

As this article was going to press, I was approached by a doctor following a talk I had given who said that she had seen an historical reference work that did discuss chastity belts as a form of contraception. The doctor said she had come across the work (said to be rooted in the 15th century) whilst studying at medical school some 30 years ago. This is of great interest to me and may be a vital link. It is true that contemporary work is not necessarily accurate or truthful (e.g. pieces in Aristotle's Masterpiece). However, the study of history is fluid, and newly found evidence is constantly informing and supplanting current views.

Should any journal readers remember having seen written documentation or published works that refer to chastity belts as a form of contraception then I would be most grateful if they could contact me at the address given in this article.

Finally, please note that I am very aware of the leather straps used as anti-masturbation devices - these are not for contraception but for contra-pleasure!

\section{Acknowledgements}

The author would like to thank the following individuals for their help and advice: Professor R Arnott, Director of the Centre for the History of Medicine, University of Birmingham Medical School, Birmingham and Dr G Williams, Curator of the British Museum, London, UK.

\section{Bibliography}

1 Trotula. A Medieval Compendium of Women's Medicine. Green, Monica H (ed.) (translated from the Latin). Philadelphia, PA: University of Pennsylvania, 2001. Good root background piece from the Salerno-based female professor of medicine writing in the 11th or 12th century covering the topics of gynaecology, obstetrics, health and hygiene. This translation has a preface that argues input from more than one individual. We do know that this text was widely referred to by physicians in Europe.

2 Lochrie, Karma; McCracken, Peggy; Schultz, James A (eds). Constructing Medieval Sexuality. Minneapolis, MN: University of Minnesota Press, 1997. Sponsored by the Centre for Medieval Studies at the University of Minnesota.

3 Karras, Ruth Mazo. Sexuality in Medieval Europe: Doing Unto Others. Abingdon, UK: Routledge, 2005.

4 Eccles, Audrey. Obstetrics and Gynaecology in Tudor and Stuart England. London, UK: Croom Helm, 1982.

5 Haynes, Alan. Sex in Elizabethan England. Stroud, UK: Sutton Publishing, 1997.

\section{About the author}

Lesley Smith is a late-16th century historian, currently studying for the degree of MPhil in the History of Medicine at Birmingham University Medical School. She has appeared in 34 television programmes including Tony Robinson's The Worst Jobs in History. Lesley is also well known as a public speaker.

\section{BOOK REVIEW}

Sensational Sex in 7 Easy Steps: The Proven Plan for Enhancing Your Sexual Function and Achieving Optimum Health. R Shabsigh, B Scali. Emmaus, PA: Rodale Books, 2007. ISBN: 1-594-86421-7. Cost: \$15.95. Pages: 352 (paperback). Website: www.shabsigh7steps.info

I have to say that when I read the title of this book, I winced - to a health professional it speaks of false promises and pointless 'how to' plans.

OK, I admit it - I was wrong. What lies behind the cover constitutes absolutely best practice in self-help material: a book for male sexual problems written by a doctor and therefore soundly based in medical practice, but which holds at its heart an awareness of the emotional and lifestyle elements of sexual dysfunction. Of course it doesn't replace diagnosis - and that fact is constantly stressed throughout the book. But as home study for interested men with or without a problem, to support medical treatment, or as a way forward if medical problems have been ruled out, it really works.

What's in there? A general introduction is followed by a self-test to indicate risk factors and then a seven-step plan that covers lifestyle changes, mental health issues, relationship problems and medical treatments. The really impressive thing is that the book treads that tricky line that all practitioners in male sexual health have surely encountered: giving men the goalfocused approach that they so often need, without letting them ignore the emotional issues that may be adding so greatly to their problem. It also stresses the role of the female partner so that she too feels included, and the reader is helped to see the importance of getting her involved in his treatment plan.
The content is absolutely sound. The style is chatty, full of convincing anecdotes and interactive sections. The language level can be high - usable only by a fairly literate patient - but the authors do make complex concepts as accessible as possible. In short, this is a useful book to recommend to patients (and their partners) or include in a clinic library.

A final note. I was sufficiently impressed by this book that I offered to join the Advisory Board of the accompanying website. But no, I am getting paid neither for that work nor for this review!

Reviewed by Susan Quilliam, BA, Cert Ed, MNLP Freelance Writer, Broadcaster and Agony Aunt, Cambridge, UK 